\title{
Działalność wybranych polskich biur podróży w Greater Toronto Area
}

\section{Activities of Selected Polish Travel Agencies in the Greater Toronto Area}

Streszczenie: Powstanie i rozwój biur podróży należy wiązać z żywiołowym rozwojem ruchu turystycznego w pierwszej połowie XIX w. Pod wpływem postępującego w tym czasie uprzemysłowienia, postępu technicznego i organizacyjnego sprzyjającego wzrostowi wydajności pracy i stopniowemu skracaniu czasu pracy, ustawowego wprowadzenia płatnych urlopów i wzrostu dochodów ludności, doszło do zmian w strukturze konsumpcji ludności, czego wyrazem było ujawnienie się nowych potrzeb w zakresie wypoczynku i turystyki. Intensywność zainteresowania oraz możliwości finansowe potencjalnych turystów spowodowały powstanie biur podroży, które zajęły się zaspokajaniem nowych potrzeb, polegającym na tworzeniu ofert dotyczących turystyki i wypoczynku (Cook, 2008). W artykule omówiona została działalność polskich biur podróży w Greater Toronto Area. Przedstawione zostały dane zebrane od 18 z 23 biur podróży działających na terenie objętym badaniem. Badania prowadzone były w latach 2016, 2017 oraz 2018. Głównym celem było ukazanie specyfiki funkcjonowania polskich biur podróży w Greater Toronto Area oraz pokazanie oferty turystycznej wybranych biur. Dzięki uzyskanym informacjom opisane zostały: destynacje najczęściej wybierane przez Polaków, liczba klientów oraz ilość wydawanych przez nich pieniędzy. Jak wykazały badania, głównymi zagranicznymi kierunkami podróży Polonii korzystającej z polskich biur podróży w Greater Toronto Area są: Kuba, Meksyk, Karaiby oraz USA. W artykule dokonana została charakterystyka największych i najprężniej działających polskich biur podróży w Toronto: Piast Travel Inc., Orbis Vacations \& Travel LTD., Polimex Travel oraz Queen Syrena Travel, ich specyficzne formy organizacji podróży (zwłaszcza do Polski) oraz oferowane przez nie wyjazdy pielgrzymkowe.

Abstract: Establishment and development of travel agencies should be associated with the vigorous development of tourist traffic in the first half of the 19th century. Under the influence of progressing industrialisation, technical and organisational progress supporting increased labour productivity and gradual shortening of working time, statutory introduction of paid leaves and higher incomes of the population, changes in the structure of population consumption took place, which manifested in the emergence of new needs in terms of relaxation and tourism. Intensity of the interest and financial possibilities of potential tourists resulted in the formation of travel agencies that dealt with satisfying newly created 
needs, consisting in providing offers regarding tourism and leisure (Cook, 2008). The article discusses the activities of the Polish travel agencies in the Greater Toronto Area which undoubtedly influence selected tourist destinations of the residents of this city. Data that was collected from 18 out of 23 travel agencies operating in the area covered by the research was presented. The research was carried out in 2017 and 2018, and thanks to the data from travel agencies, destinations that are most frequently chosen by Poles, the number of clients, the amount of money spent by them, as well as the specificity of functioning of Polish travel agencies in Toronto were described. The article presents the characteristics of the largest and most-active Polish travel agencies in Toronto, such as: Piast Travel Inc., Orbis Vacations \& Travel LTD., Polimex Travel, and Queen Syrena Travel, their specific forms of travel organisation (especially travel to Poland) and pilgrimage trips offered by travel agencies.

Słowa kluczowe: biuro podróży; Kanada; Polonia; Toronto; turystyka

Keywords: Canada; Polish people; Toronto; tourism; travel agencies

Otrzymano: 30 stycznia 2019

Received: 30 January 2019

Zaakceptowano: 12 sierpnia 2019

Accepted: 12 August 2019

\section{Sugerowana cytacja/Suggested citation}

Ziółkowska-Weiss K. (2019). Działalność wybranych polskich biur podróży w Greater Toronto Area. Przedsiębiorczość - Edukacja [Entrepreneurship - Education], 15(2), 184-199. doi: $10.24917 / 20833296.152 .13$

\section{Wstęp}

Wielokulturowość miast odczytujemy przez pryzmat cech kulturowych i społecznych mieszkańców, a także miejskiej architektury. Fundamentem wielokulturowości miast jest zjawisko migracji, które kieruje rzesze ludzi w ich granice. Przynoszą oni ze sobą zróżnicowane wzorce kulturowe, etniczne i społeczne. Skupieni w jednej przestrzeni tworzą mozaikowy obraz, przedstawiający ludzi o zróżnicowanym ubiorze, nakryciu głowy, języku, poglądach oraz stylu i standardzie życia. Miasta odgrywają zatem ważną rolę w procesie rozwoju kultur, gdyż mają własną organizację, obejmującą grupy społeczne o specyficznych funkcjach. $Z$ socjologicznego punktu widzenia istotnym skutkiem rozrostu miast jest rozwój grup społecznych, kultywujących różnorakie elementy kultur narodowych.

Obok obszernej literatury na temat grup etnicznych zamieszkujących Toronto nie było do tej pory publikacji naukowej dotyczącej analizy interesującego autorkę zagadnienia - aktywności turystycznej Polonii mieszkającej w Greater Toronto Area (GTA). Jest to tymczasem ważne zagadnienie z punktu widzenia socjologicznego, migracyjnego oraz kulturowego. $Z$ danych statystycznych wynika, że pomimo stosunkowo restrykcyjnych przepisów i planów dodatkowego ich zaostrzenia, Kanada wciąż pozostaje krajem atrakcyjnym dla przybyszów i o nich zabiegającym (Hays, 2003). Przyjmuje ona rocznie około ćwierć miliona nowych imigrantów. Kraj ten ma, obok Australii, najwyższy na świecie wskaźnik imigrantów w przeliczeniu na jednego mieszkańca. Dodatnie saldo imigracyjne sprawia, że Kanada wykazuje się najwyższym poziomem wzrostu ludności wśród krajów grupy G8 i jednym z najwyższych wśród krajów wysoko rozwiniętych (Population growthrate, 2017). Warto zatem było przeanalizować i zbadać, czy kanadyjska Polonia jest zadowolona z życia w tym kraju i jak przedstawia się jej aktywność turystyczna w ciągu roku. 
Powstanie i rozwój biur podróży należy wiązać z żywiołowym rozwojem ruchu turystycznego w pierwszej połowie XIX w. Pod wpływem postępującego w tym czasie uprzemysłowienia, postępu technicznego i organizacyjnego sprzyjającego wzrostowi wydajności pracy i stopniowemu skracaniu czasu pracy, ustawowego wprowadzenia płatnych urlopów i wzrostu dochodów ludności, doszło do zmian w strukturze konsumpcji, których wyrazem było ujawnienie się nowych potrzeb w zakresie wypoczynku i turystyki (Ziółkowska-Weiss, 2016). Intensywność zainteresowania oraz możliwości finansowe potencjalnych turystów spowodowały powstanie biur podroży, które zajęły się zaspokajaniem nowych potrzeb, polegającym na tworzeniu ofert dotyczących turystyki i wypoczynku (Cook, 2008). Celem niniejszego artykułu jest omówienie działalności największych i najprężniej funkcjonujących polskich biur podróży w Toronto, które niewątpliwie wpływają na wybierane przez mieszkańców tego miasta kierunki turystyczne. Głównym celem badań było określenie, jak Polonia mieszkająca w GTA, w skład którego wchodzą: miasto Toronto oraz cztery regiony: Halton, Peel (na terenie którego leży samo miasto Mississauga, zaliczane do najliczniej zamieszkałych przez Polonię), York oraz Durham, jest aktywna turystycznie oraz jakie znaczenia dla polskiej diaspory w Kanadzie ma funkcjonowanie polskich biur podroży.

\section{Polonia w Greater Toronto Area}

Kanada to kraj o imigracyjnym rodowodzie, który ze względu na oferowany standard życia przyciąga rzesze imigrantów ze wszystkich stron świata. Toronto to współczesna wielokulturowa metropolia, która mieści w sobie całe spektrum społecznych i kulturowych zróżnicowań (Mamzer, 2003). To przestrzeń o widocznym zróżnicowaniu etnicznym i rasowym mieszkańców, która respektuje przypisane im symbole. Wielokulturowość określona przez Fisha (1997) jako silna przejawia się nade wszystko w etnicznym zróżnicowaniu mieszkańców współczesnych miast. Metropolią obrazującą taki stan rzeczy niewątpliwie jest największe miasto Kanady - Toronto, założone w roku 1793, które można nazwać wielokulturową stolicą świata. Dzisiaj mieszkają w nim przedstawiciele ponad 200 grup etnicznych, co sprawia, że miasto to jest bardziej zróżnicowane etnicznie niż Miami, Los Angeles czy Nowy Jork. Zgodnie z danymi najnowszego spisu narodowego (2016), w Toronto mieszka 2,5 mln, a w GTA - 5,5 mln ludzi. W latach 2001-2006 na terytorium Toronto osiedliło się 267855 imigrantów (City of Toronto...). Dane z roku 2011 pokazują, iż 47\% populacji Toronto zalicza się do widocznych mniejszości. Wśród nich najliczniejszą grupę stanowią imigranci z Azji Południowej (298 372, czyli 12\% populacji), Chińczycy (283 075 - 11,4\%), Afrokanadyjczycy (Murzyni) (208 555 - 8,4\%), Filipińczycy (102 555 - 4,1\%) oraz imigranci z Ameryki Łacińskiej (64 860 - 2,6\%), Azji Zachodniej (42 755 - 1,7\%), Azji Południowo-Wschodniej (37 495 - 1,5\%), Koreańczycy (34 220 - 1,4\%), Arabowie (22 485 - 0,9\%) oraz Japończycy (11 965 - 0,5\%). Wśród pozostałych mieszkańców kanadyjskiej metropolii 19\% stanowią imigranci o rodowodzie brytyjskim (Anglia, Szkocja, Irlandia) (Reczyńska, 2001). Pozostała część populacji Toronto, która nie jest zaliczana do widocznych mniejszości, liczy 1313930 osób, czyli 53,1\%. W tej liczbie mieszczą się także rdzenni mieszkańcy Kraju Klonowego Liścia. Tymczasem na terytorium Kanady żyje ogółem 5 mln przedstawicieli visible minority, z których 96\% mieszka w miastach, stanowiąc 68\% wszystkich mieszkańców kanadyjskich metropolii. Przed 1961 r. ludność kolorowa stanowiła 3\% populacji Toronto (Anisef, Lanphier, 2003). 
Toronto staje się powoli obcym miastem dla ludzi mieszkających tutaj od pokoleń. To przede wszystkim potomkowie imigrantów europejskich, którzy przenoszą się na peryferie miasta. Dzisiaj miejscem, do którego udają się „wypchnięci” z centrum mieszkańcy Toronto, jest przede wszystkim Mississauga, gdzie mieszka największa liczba osób polskiego pochodzenia i gdzie znajduje się największy na świecie polski kościół parafialny poza granicami Polski.

Współczesne rozmieszczenie Polaków w Kanadzie zostało uwarunkowane z jednej strony procesami rozwoju młodego państwa, a z drugiej strony - przemianami społecznymi zachodzącymi w samej Polonii. Aż do lat 30. XX w. imigranci z Europy Środkowej byli kierowani przez władze kanadyjskie na obszary rolnicze w prowincjach Manitoba, Saskatchewan, Alberta. Dopiero po II wojnie światowej Polacy zaczęli osiedlać się głównie w miastach. Procesy urbanizacyjne sprawiły, że już w latach 70. XX w. 80\% Polaków mieszkało w miastach, przede wszystkim w dużych aglomeracjach prowincji Ontario i Quebec (Kijewska-Trembecka, 2013). Obecnie główne skupiska Polonii to miasta, przede wszystkim Toronto, a w dalszej kolejności: Montreal, Ottawa, Edmonton, Hamilton, Vancouver, Winnipeg, Calgary. Przedstawiciele najnowszych fal polskich migrantów z drugiej połowy XX w. osiedlali się głównie w Toronto, stąd zdecydowana dominacja liczebna mieszkającej tam Polonii. W tym mieście działają najbardziej aktywne organizacje i ukazuje się najwięcej tytułów prasy polonijnej (Reczyńska, 2006).

Według danych kanadyjskiego spisu powszechnego z 2006 r., w Kanadzie mieszkało wówczas 984 tys. osób deklarujących polskie pochodzenie (łącznie - polskie pochodzenie jako najważniejsze oraz polskie korzenie wśród innych), co daje ponad 3\% całej populacji Kanady (Statistics Canada, 2006). Natomiast według danych z 2011 r. językiem polskim władało nieco ponad 190 tys. Kanadyjczyków (Statistics Canada, 2011).

Na przełomie XIX i XX w. Polacy licznie przybywali do Kanady i osiedlali się głównie w zachodnich prowincjach. Stanowili oni część przybyszów z Europy Środkowej, których określano mianem Galicjan lub ludzi w baranich skórach (Reczyńska, 2010). Podając za A. Reczyńską, do 1914 r. przybyło na ziemie kanadyjskie ok. 60 tys. Polaków (Reczyńska, 2014). Po zakończeniu II wojny światowej Kanadyjczycy otworzyli swoje granice dla uchodźców wojennych oraz tzw. dipisów (displaced persons). Jak pisze M. Marczuk-Karbownik (2016), displaced persons to określenie używane w stosunku do migrantów, głównie z Europy Środkowo-Wschodniej, którzy w wyniku wydarzeń wojennych nie mogli bądź nie chcieli wrócić do ojczyzny. Szacuje się, że w tej grupie znajdowało się ok. 55 tys. Polaków, którzy w latach 1945-1955 zamieszkali w Kanadzie (Reczyńska, 2014). Kolejny znaczący napływ Polaków miał miejsce w latach 80. i 90., kiedy to do Kanady przybyła grupa tak zwanych postsolidarnościowych imigrantów w liczbie 115 tys. Powojenni przybysze osiedlali się głównie w Ontario, zwłaszcza w Toronto i jego okolicach (miasto Mississauga), tworząc z tego regionu centrum polskiej diaspory w Kanadzie (Reczyńska, 2006).

Kanadyjska część, rozrzuconej po świecie, diaspory polskiej to polscy emigranci oraz osoby polskiego pochodzenia, które w Kanadzie określane są jako polska grupa etniczna. Według danych spisu powszechnego z roku 2001, mieszkało wówczas w tym kraju 260415 osób określających swe pochodzenie jako polskie. Kategoria ta uwzględnia wyłącznie respondentów wymieniających identyfikację jedynie z grupą polską jako dla nich najważniejszą (single response). Pochodzenie polskie obok innych (multiple response) deklaruje w Kanadzie 556665 osób (City of Toronto..., 2001). 
Jak piszą A. Reczyńska i T. Soroka (2013), w roku 1991 w zestawieniu dziesięciu krajów stanowiących najważniejsze źródła imigracji do Kanady Polska znajdowała się na drugim miejscu (za Hongkongiem). W roku 1996 przesunęła się na miejsce szóste (za Hongkongiem, Chinami, Indiami, Filipinami i Sri Lanką), ale nadal wyprzedzała inne kraje europejskie. Od roku 2001 Polska zniknęła już z pierwszej dziesiątki (Statistics Canada, 2006a). Dostępne statystyki kanadyjskie zamieszczają w związku z tym znacznie mniej danych na temat struktury polskich imigrantów niż na temat grup od nich większych. Dlatego proponowane socjologiczno-kulturowe badania stanowiłyby doskonałe uzupełnienie informacji o polskiej diasporze najliczniej zamieszkanego przez Polonię miasta w Kanadzie, jakim jest obszar Greater Toronto Area. Warto zatem przeanalizować i zbadać, czy kanadyjska Polonia mieszkająca w wielokulturowym Toronto, jest aktywna turystycznie, jakie kierunki podroży wybiera najczęściej i jak często korzysta z polskich biur podroży działających w Toronto.

\section{Przebieg, metody oraz zakres czasowy i przestrzenny badań empirycznych}

Zasadniczym obszarem prowadzonych badań był Greater Toronto Area, który zostało wybrany ze względu na najliczniej zamieszkującą go grupę Polonii w Kanadzie. Badaniami empirycznymi objęto pięć regionów wchodzących w skład Graeter Toronto Area. Były to: region Peel, region Halton, region York, region Durham oraz samo miasto Toronto. Okres czasowy prowadzonych badań obejmował lata 2016, 2017 oraz 2018. W roku 2016 przeprowadzone zostały badania pilotażowe, natomiast badania właściwe w Kanadzie prowadzone były w dwóch etapach. Etap pierwszy badań terenowych miał miejsce w dniach 11-29 września 2017 r., natomiast etap drugi w dniach 16-18 września 2019 r. Podczas prowadzonych badań autorka zastosowała zarówno metody jakościowe, jak i ilościowe. Do badań ilościowych należy metoda sondażu diagnostycznego w postaci badań ankietowych. Podstawową bazę empiryczną stanowiły wyniki badań przeprowadzonych wśród Polonii mieszkającej w Greater Toronto Area. Część empiryczna badań miała formę sondażu diagnostycznego, przeprowadzonego metodą reprezentacyjną wśród populacji Polonii Greater Toronto Area. Badania właściwe objęły w sumie 1267 respondentów, z czego do analizy wykorzystano 1150 kwestionariuszy ankietowych. Ta część analizy badawczej nie została opisana w niniejszym artykule, jednak chciano zwrócić uwagę na zastosowaną metodologię podczas badań terenowych. W tym opracowaniu skupiono się na drugiej metodzie badawczej jaką zastosowanej podczas badań terenowych. Badania te należą do badań jakościowych i były to przeprowadzone indywidualne pogłębione wywiady z właścicielami oraz pracownikami biur podróży działających w Greater Toronto Area. Na podstawie przeprowadzonych rozmów przeanalizowano destynacje turystyczne najczęściej wybierane przez kanadyjską Polonię oraz scharakteryzowano biura podróży najprężniej działające na terenie objętym badaniem. Badania jakościowe rodowód swój czerpią z badań etnograficznych, które z kolei - jako pewien specyficzny model badawczy - są zakorzenione w antropologii. W stosunku do badań ilościowych badania jakościowe koncentrują się na głębszej analizie badanych zjawisk, główny nacisk kładąc na to, aby za pomocą specjalnych technik lepiej i dokładniej je zrozumieć. W badaniach jakościowych badacz stara się patrzeć na rzeczywistość oczami badanych, starając się nie sugerować z góry przyjętymi przez siebie przypuszczeniami lub schematami rozumowania (Alejziak, 2005). Nie chodzi bowiem w nich o ilościowe ujmowanie danych na temat przedmiotu 
badań, ale o uzyskanie jakościowo dobrych informacji, poszerzających stan wiedzy o badanym zjawisku. O ile w badaniach ilościowych zazwyczaj badane są zjawiska już dosyć dobrze znane i z góry określone, o tyle badania jakościowe często dostarczają zupełnie nowej wiedzy. Wynika to z założenia, że techniki pozyskiwania informacji nie powinny ograniczać badanych (w badaniach ilościowych odpowiedzi najczęściej są podane, np. $\mathrm{w}$ kwestionariuszu ankiety, a respondenci wskazują na jedną z nich, natomiast w badaniach jakościowych odpowiedzi uzyskiwane są od samych badanych osób w taki sposób, że badacz nie zakłada z góry, jakie one będą). Dzięki takiemu podejściu możliwe jest uzyskanie nietypowych danych, spojrzenie na analizowane zagadnienie $\mathrm{z}$ innej perspektywy. W badaniach jakościowych celem nie jest uzyskanie odpowiedzi na pytanie „ile?”, ale „jak? i „dlaczego?”. Czyli przykładowo: o ile badania ilościowe danego produktu turystycznego mierzą, jak często jest on kupowany i na ile podoba się on klientom, o tyle badania jakościowe dostarczają informacji, dlaczego klienci wybierają ten produkt oraz co sprawia, że się nim interesują (Alejziak, 2008). Badania jakościowe są dominującą metodą $\mathrm{w}$ antropologii, socjologii, psychologii, a także organizacji i zarządzaniu. Natomiast w naukach przyrodniczych opierają się najczęściej na porównaniu właściwości lub zachowania obiektu badań ze znanymi wzorcami. Badania jakościowe mają pewne wady. W przeciwieństwie do badań ilościowych są mało usystematyzowane i raczej nie stosuje się w nich wnioskowania statystycznego. Ich wadą jest też to, że zazwyczaj nie pozwalają na szerokie uogólnienia i generalizacje (np. na całą populację), gdyż nie są reprezentatywne, a także to, że mogą być podatne na subiektywną ocenę badacza. Są też najczęściej bardziej czasochłonne niż badania ilościowe (Jasiński, Kowalaski, 2007).

\section{Działalność polskich biur podróży w Chicago}

Głównych celem artykułu jest przedstawienie największych i najprężniej działających polskich biur podróży zlokalizowanych w Greater Toronto Area, których działalność ma niewątpliwy wpływ na destynacje turystyczne wybierane przez mieszkańców Toronto. Dane zebrano z 18 z 23 biur podróży działających na terenie objętym badaniem. Dzięki danym $z$ biur podróży poznano destynacje najczęściej wybierane przez Polaków, liczbę klientów, ilość wydawanych przez nich pieniędzy oraz specyfikę funkcjonowania biur podróży w Greater Toronto Area. Największe polskie biura podroży, takie jak Piast Travel, Polimex Travel czy Queen Syrena Travel, mają swoje siedziby w kilku miejscach objętym badaniem. W ich przypadku badania przeprowadzone zostały w różnych siedzibach. Nazwy oraz adresy polskich biur podróży, które znajdują się w Greater Toronto Area, zostały przedstawione $\mathrm{w}$ tabeli 1 .

Jednym z narzędzi zastosowanym podczas badań, należącym do narzędzi badań jakościowych, były przeprowadzone indywidualne pogłębione wywiady z właścicielami oraz pracownikami biur podróży działających w Greater Toronto Area, na podstawie których dokonano analizy najczęściej wybieranych przez kanadyjską Polonię destynacji turystycznych.

Podczas przeprowadzanych badań ważne informację uzyskano w biurach Piast Travel, Polimex Travel oraz Syrena Queen Travel. Autorka rozmawiała również z właścicielami bądź pracownikami następujących biur podróży: Orbis Vacations and Travel LTD, Vistula Travel Inc. oraz Caniaga Travel. 
Tabela 1. Polskie biura podróży, które znajdują się w Greater Toronto Area

\begin{tabular}{|c|l|l|}
\hline Lp. & \multicolumn{1}{|c|}{ Nazwa biura podróży } & \multicolumn{1}{c|}{ Adres biura podroży } \\
\hline 1. & Piast Travel & $\begin{array}{l}\text { 35 King St. E Unit 19, Mississauga } \\
\text { 2265 Royal Windsor Dr Unit 5B, Mississauga } \\
\text { 2010 Dundas St. E, Mississauga } \\
\text { 175 Toryork Dr Weston, Mississauga } \\
\text { 20 Polonia Ave, 111, Brampton } \\
\text { 113 RoncesvallesAve, Toronto }\end{array}$ \\
\hline & & $\begin{array}{l}\text { 3615 Dixie Rd., Unit 11, Mississauga } \\
\text { 3145 Dundas St. West Unit 6, Mississauga } \\
\text { 190 bovairdRd. W. Unit 59, Brampton } \\
\text { 141 RoncesvallesAve, Toronto } \\
\text { 3482 Lawrence Ave, 104 Scarborough }\end{array}$ \\
\hline 3. & & $\begin{array}{l}\text { 3115 Dundas St. W Unit 8, Mississauga } \\
\text { 3055 Dundas St. W Unit 4, Mississauga }\end{array}$ \\
\hline 4. & Qrbis Vacations and Travel & 2065 Dundas Str. E 107, Mississauga \\
\hline 5. & All In One Travel - Anna Biały & 1900 Dundas St. E 1, Mississauga \\
\hline 6. & Centre Holidays Inc. - Barbara & 2155 LeanneBlv. 214, Mississauga \\
\hline 7. & Vistula Travel Inc. & 408 OaktreeCir., Mississauga \\
\hline 8. & Westend Travel Inc. & 3015 PorkerhillRd, 6, Mississauga \\
\hline 9. & Caniaga Travel & 17 Westglen Cres, Toronto \\
\hline 10. & Expol International Travel & 695 MarkhemRd.Stv 27, Toronto \\
\hline 11. & Hanna Travel Inc. & 660 The Queensway, Toronto \\
\hline 12. & Travel Goodtime Tours & 777 WordenAve S.215, Toronto \\
\hline
\end{tabular}

Źródło: opracowanie własne

Niezwykle przydatne dane autorka otrzymała do Katarzyny Czosnyki i Agnieszki Januszkiewicz, które pracują w Queen Syrena Travel, oraz od Renaty Puz z Polimex Travel. Pani Mariola Labuda-Kidaj pracująca w Orbis Vacations and Travel LTD podzieliła się informacjami dotyczącymi liczby sprzedawanych biletów lotniczych oraz najczęściej wybieranych kierunków wypoczynkowych. Natomiast pani Grażyna Pochron udzieliła informacji turystycznych i opowiedziała również o historii funkcjonowania biura podroży Piast Travel Inc., w którym na co dzień pracuje.

Największe i najdłużej działające biura podróży swoje siedziby mają w kilku miejscowościach oraz kilku punktach na terenie Greater Toronto Area. Najwięcej z nich znajduje się w Mississauga, gdzie od kilkunastu lat przebywa największa grupa Polonii w Kanadzie. Lokalizacja poszczególnych biur podróży w bliskim sąsiedztwie stałego zamieszkania Polonii niewątpliwie wpływa na ułatwienie i szybszy dostęp do poszczególnych punktów obsługi klienta. Jak podkreślali pracownicy poszczególnych biur podróży w Mississauga, pomimo łatwego i powszechnego dziś dostępu do internetu, a co za tym idzie - możliwości wykupienia wycieczki za pośrednictwem istniejących turystyczno-podróżniczych stron internetowych, Polonia w Greater Toronto Area mimo wszystko wybiera tradycyjną drogę zakupu oferty turystycznej i w tym celu osobiście udaje się do biura podróży, gdzie dokonuje wszystkich formalności związanych z wyjazdem turystycznym. Zdaniem Katarzyny Czosnyki z Queen Syrena Travel, ich klienci w ten sposób mają pewność 
dokonanej transakcji, mogą zapytać agenta turystycznego o wszystkie aspekty związane z samym wyjazdem, a dodatkowa opieka turystyczna przed wyjazdem i w trakcie jego trwania daje poczucie bezpieczeństwa związanego z procesem przygotowania do wyjazdu, jak i w jego trakcie.

Spośród oferty biur podróży działających w Greater Toronto Area bardzo popularne i często wykupowane przez Polonię są jednodniowe lub dwudniowe wycieczki. Wyjazdy te umożliwiają poznanie miast, bliższych i tych dalszych, jak Quebec, Montreal, Ottawa, a także miast w USA, np. Nowego Yorku czy Chicago. Oferta takich wyjazdów jest bogata i nie różni się zbytnio programami pomiędzy różnymi organizatorami. Jednodniowe wyjazdy są idealnym sposobem aktywnego spędzenia czasu wolnego bez konieczności dłuższego urlopu, dlatego ich program nie jest zbyt przeładowane atrakcjami. Wśród wyjazdów dłuższych, trwających ponad 5 dni, można wyróżnić kilka wiodących kierunków, w zależności również od poszukiwanej formy wypoczynku - wycieczki objazdowej lub ciągłego pobytu, którego głównym celem jest relaks i wypoczynek. Jeśli chodzi o wyjazdy długoterminowe, trwające tydzień lub dwa, są to głównie wyjazdy wypoczynkowe. Najczęściej wybieranymi przez kanadyjską Polonię kierunkami są Kuba, Meksyk i Karaiby (Dominikana). Najczęściej wybieranymi miejscowościami podczas wypoczynku są Punta Cana na Dominikanie oraz Riviera Maya i Cancun w Meksyku. Najpopularniejszymi miejscowościami wypoczynkowymi wśród Polonii z Greater Toronto Area na Kubie są: Varadero, Santa Maria, San Antonio oraz Matanzas. Taki wybór destynacji turystycznej spowodowany jest dużą ofertą hoteli na wyspie, możliwością szybkiej podroży (samolot z Toronto do Havany leci ok. 3,5 godz.), pewną, słoneczną pogodą oraz - co szczególnie podkreślają i co doceniają podróżni z Greater Toronto Area - brakiem konieczności zmiany strefy czasowej (tzw. podróżowanie po południku) i adaptacji fizjologicznej, co jest konieczne w przypadku podróży chociażby do Europy. Kuba wybierana jest często przez podróżnych z Kanady również dlatego, że tygodniowy pobyt wypoczynkowy na tej wyspie, w hotelu średniej klasy kosztuje ok. 800-1000 CAD. To wydatek, na który większa liczba osób mających stałą pracę w Kanadzie, śmiało może sobie pozwolić. Za podobny komfort wypoczynku na Dominikanie trzeba zapłacić około 1200-1500 CAD, a w Meksyku - 1500-2000 CAD.

\section{Działalność biura podroży Polimex Travel}

Polimex Travel jest polonijną firmą działającą na rynku kanadyjskim od 1982 r. Biuro swoją siedzibę ma w kilku miejscach: w Brampton, Toronto, Scarborough oraz dwa oddziały w Mississauga. Polimex Travel to firma, której pracownicy dzięki swojej fachowości, doświadczeniu i wiedzy oferują klientom wachlarz usług na najwyższym poziomie. Biuro podroży zatrudnia fachowców nieustannie doskonalących się w wybranej dziedzinie przez kursy szkoleniowe, wyjazdy oraz szkolenia wewnątrz firmy. Biuro podroży specjalizuje się w wyjazdach grupowych i indywidualnych do Polski oraz do innych krajów europejskich. Specjalnością biura są również wycieczki autokarowe po Kanadzie i do USA, które $z$ roku na rok przyciągają coraz szersze grono podróżujących. W tabeli 2 przedstawiono przykłady wyjazdów autokarowych, zorganizowanych w roku 2018 przez biuro podróży Polimex Travel. 
Tabela 2. Przykłady autokarowych wycieczek organizowanych przez Polimex Travel w 2018 r.

\begin{tabular}{|l|l|c|c|}
\hline \multicolumn{1}{|c|}{ Wycieczka } & \multicolumn{1}{|c|}{ Data } & Cena w CAD & Liczba uczestników \\
\hline Ottawa & 6-8 lipca 2018 & 619 & 65 \\
\hline Nowy York & 20-23 lipca 2018 & 725 & 78 \\
\hline Nowy York & 31 sierpnia-3 września 2018 & 725 & 64 \\
\hline Chicago & 24-27 sierpnia 2018 & 769 & 68 \\
\hline
\end{tabular}

Źródło: opracowanie własne

Jednym z najwcześniej wybieranych miast wśród klientów Polimex Travel jest Nowy York. Co roku biuro podroży organizuje kilkudniowe wycieczki do tego miasta, a popularność tej oferty nie zmienia się od kilku lat.

Polimex Travel specjalizuje się również w organizowaniu dalekich, egzotycznych podroży. Tabela 3 przedstawia wybrane, dalekie wycieczki organizowane przez to biuro, ich kosz oraz liczbę podróżnych w roku 2017 i 2018. Są to wycieczki organizowane z rocznym wyprzedzeniem, a większość klientów wybierających się w taką podróż to stali klienci firmy, którzy co roku podróżują z firmą Polimex Travel. Jak podkreśliła w wywiadzie pani Renata Puz, jedna $\mathrm{z}$ osób pracujących od lat w firmie, $80 \%$ klientów biura podróży Polimex Travel to stali, wierni od lat klienci opisywanego biura. Wśród polskich klientów biura na tego typu wyjazdy chętni są również przedstawiciele ukraińskiej czy czeskiej grupy narodowościowej, którzy stanowią ok. 25\% z wszystkich obsługiwanych w biurze klientów.

Tabela 3. Wybrane wycieczki do egzotycznych krajów organizowane przez Polimex Travel w 2017 i $2018 \mathrm{r}$.

\begin{tabular}{|l|l|c|c|}
\hline \multicolumn{1}{|c|}{ Wycieczka } & \multicolumn{1}{|c|}{ Data wyjazdu } & \multicolumn{1}{c|}{$\begin{array}{c}\text { Cena } \\
\text { w CAD }\end{array}$} & $\begin{array}{c}\text { Liczba } \\
\text { uczestników } \\
\text { 2018/2019 r. }\end{array}$ \\
\hline The Best of Peru & 8-17 października 2018 & 2699 & 43 \\
\hline $\begin{array}{l}\text { Magiczny Dubaj i Abu } \\
\text { Dhabi }\end{array}$ & $\begin{array}{l}\text { 18-25 październik 2018, } \\
\text { 9-16 lutego 2019 }\end{array}$ & 1990 & 96 \\
\hline Chiński Złoty Trójkąt & 23 październik-3 listopada 2018 & 1799 & 160 \\
\hline Kolumbia w Pigułce & 2-9 lutego 2018 & 3599 & 24 \\
\hline $\begin{array}{l}\text { Maroko Cesarskie } \\
\text { Miasta }\end{array}$ & 28 marca-6 kwietna 2018 & 2299 & 37 \\
\hline Egzotyczna Tajlandia & $\begin{array}{l}\text { 23 lutego-7 marca 2018 } \\
\text { 9-21 marca 2018 }\end{array}$ & 2699 & 73 \\
\hline Skarby Indii & 8 lutego-18 lutego 2018 & 2199 & 59 \\
\hline Bali & 18-26 lutego 2018 & 2399 & 34 \\
\hline
\end{tabular}

Źródło: opracowanie własne

Wśród egzotycznych wypraw na szczególną uwagę zasługuje wzrost zainteresowania Chinami. Biuro podróży ma w swojej ofercie wycieczkę pt.: „Chiński Złoty Trójkąt”, z której oferty w roku 2017 skorzystało 89 uczestników, a w roku 2018 było to już 160 osób. Na uwagę zasługują również takie kierunki, jak Dubaj czy Tajlandia. W roku 2017 
biuro nie wysłało do tych krajów żadnego podróżnego, podczas gdy rok później takich osób było już odpowiednio: dla Tajlandii 73 osoby, a dla Dubaju 96 osób.

Biuro podróży Polimex Travel specjalizuje się również w organizacji pielgrzymek po świecie. Tabela 4 przedstawia wybrane pielgrzymki organizowane przez biuro, ich datę w 2018 r. oraz liczbę uczestników wyjazdu w 2017 oraz 2018 r.

Tabela 4. Wybrane pielgrzymki organizowane przez Polimex Travel

\begin{tabular}{|l|l|c|c|c|}
\hline \multicolumn{1}{|c|}{ Pielgrzymka } & $\begin{array}{c}\text { Data pielgrzymki } \\
\text { w 2018 r. }\end{array}$ & $\begin{array}{c}\text { Cena } \\
\text { w CAD }\end{array}$ & $\begin{array}{c}\text { Liczba } \\
\text { uczestników } \\
\text { w 2017 r. }\end{array}$ & $\begin{array}{c}\text { Liczba } \\
\text { uczestników } \\
\text { w 2018 r. }\end{array}$ \\
\hline $\begin{array}{l}\text { Pielgrzymka do Sanktuarium } \\
\begin{array}{l}\text { Matki Boskiej z Guadalupe } \\
\text { (wraz z oo. oblatami z Parafii } \\
\text { pw. św. M. Kolbe w Mississauga) }\end{array}\end{array}$ & $\begin{array}{l}9-14 \text { grudnia } \\
2018\end{array}$ & 1645 & 85 & 105 \\
\hline $\begin{array}{l}\text { Pielgrzymka do Ziemi Świętej } \\
\text { i Jordanii (wraz z oo. oblatami } \\
\text { z Parafii pw. św. M. Kolbe } \\
\text { w Mississauga) }\end{array}$ & $\begin{array}{l}30 \text { kwietnia-10 } \\
\text { maja 2018 }\end{array}$ & 3990 & 35 & 54 \\
\hline
\end{tabular}

Źródło: opracowanie własne

Każdego roku bardzo popularna jest pielgrzymka do Sanktuarium Matki Boskiej z Guadalupe w Meksyku, która organizowana jest wraz z ojcami oblatami z Parafii pw. św. M. Kolbe w Mississauga, będącej największą polską parafią działającą poza granicami Polski. Duża grupa uczestników tej pielgrzymki to stali parafianie tego kościoła, dla których często główną motywacją wyjazdu na pielgrzymkę jest fakt, że jadą oni ze swoimi księżmi z parafii. Również pielgrzymka do Ziemi Świętej, do Izraela, pomimo wysokich kosztów podróży, co roku znajduje klientów i jest regularnie organizowana.

Biuro podróży Polimex Travel jest obecnie jedynym w całości polskim biurem podróży działającym w Greater Toronto Area. Oznacza to, że udziały w tej firmie w 100\% należą do Polaków. W przypadku innych biur podróży istnieją współwłaściciele, którzy mają inne pochodzenia niż polskie, a ich udziały w polskich biurach podroży stanowią ok. 30-40\% wszystkich udziałów w firmie. Dlatego też Polimex Travel co roku z dużymi sukcesami i wiernymi klientami przygotowuje mnóstwo ofert związanych z możliwością wyjazdu do Polski i poznaniem polskiej kultury oraz polskich, flagowych turystycznych miejsc. Tabela 5 przedstawia wybrane wycieczki do Polski organizowane przez Polimex Travel.

Tabela 5. Wybrane wycieczki do Polski organizowane przez Polimex Travel

\begin{tabular}{|c|l|c|c|l|}
\hline \multicolumn{1}{|c|}{ Wycieczka } & \multicolumn{1}{|c|}{ Trasa wycieczki } & $\begin{array}{c}\text { Cena } \\
\text { w CAD }\end{array}$ & $\begin{array}{c}\text { Liczba } \\
\text { dni }\end{array}$ & $\begin{array}{c}\text { Daty wyjazdów } \\
\text { w 2018 r. }\end{array}$ \\
\hline Magic od Poland & $\begin{array}{l}\text { Warszawa - Częstochowa - } \\
\text { Zakopane - Oświęcim - } \\
\text { Wieliczka - Kraków }\end{array}$ & 2049 & 7 dni & $\begin{array}{l}11 \text { maj } \\
1,15 \text { czerwca } \\
6,20 \text { lipca } \\
10,24 \text { sierpnia } \\
7,21 \text { września } \\
5 \text { października }\end{array}$ \\
\hline
\end{tabular}




\begin{tabular}{|c|c|c|c|c|}
\hline $\begin{array}{l}\text { Treasures } \\
\text { of Poland }\end{array}$ & $\begin{array}{l}\text { Warszawa - Częstochowa - } \\
\text { Zakopane - Kraków - } \\
\text { Oświęcim - Wieliczka - Łowicz - } \\
\text { Toruń - Gdynia - Gdańsk - } \\
\text { Sopot - Warszawa }\end{array}$ & 3299 & $11 \mathrm{dni}$ & $\begin{array}{l}11 \text { maja } \\
1,15 \text { czerwca } \\
6,20 \text { lipca } \\
10,24 \text { sierpnia } \\
7,21 \text { września } \\
5 \text { października }\end{array}$ \\
\hline $\begin{array}{l}\text { Many Faces od } \\
\text { Poland }\end{array}$ & $\begin{array}{l}\text { Warszawa - Częstochowa - } \\
\text { Oświęcim - Kraków - Wieliczka - } \\
\text { Zakopane - Wadowice - } \\
\text { Wrocław - Rydzyna - Poznań - } \\
\text { Toruń - Gdynia - Gdańsk - } \\
\text { Sopot - Malbork - Olsztyn - } \\
\text { Łowicz - Warszawa }\end{array}$ & 3899 & $14 \mathrm{dni}$ & $\begin{array}{l}13 \text { lipca } \\
7 \text { sierpnia }\end{array}$ \\
\hline $\begin{array}{l}\text { Southern } \\
\text { Adventures }\end{array}$ & $\begin{array}{l}\text { Warszawa - Częstochowa - } \\
\text { Zakopane - Kraków - } \\
\text { Oświęcim - Wadowice - } \\
\text { Wieliczka - Łowicz - Warszawa }\end{array}$ & 2799 & $9 \mathrm{dni}$ & $\begin{array}{l}18 \text { maja } \\
6 \text { czerwca } \\
13 \text { lipca } \\
17 \text { sierpnia } \\
7 \text { września }\end{array}$ \\
\hline
\end{tabular}

Źródło: opracowanie własne

Oferta jest bardzo zróżnicowana. Dostępne są różne programy, liczba oferowanych dni w podróży oraz zapłata za usługę. Najbardziej popularnymi miesiącami, kiedy Polonia udaje się do miejsc swoich przodków, są maj, czerwiec, lipiec, sierpień oraz wrzesień.

\section{Queen Syrena Travel - turystyka pielgrzymkowa}

Innym godnym uwagi biurem podróży działającym w Greater Toronto Area jest Queen Syrena Travel. To biuro podróży, poza regularną ofertą wyjazdów do Polski, na Karaiby, Kubę czy do Meksyku, specjalizuje się w turystyce pielgrzymkowej. Swoją działalność prowadzi od 1989 r., a siedzibę ma w dwóch miejscach w Mississauga. W dziale obsługi klienta pracuje na stałe osiem Polek, a w dziale księgowości pracują trzy osoby. Wśród zatrudnionych osób znajduje się też Ukrainka, która obsługuje klientów głównie z Ukrainy. Jak podkreśla Agnieszka Januszkiewicz, jedna z osób pracujących w Queen Syrena Travel, wśród obsługiwanych klientów poza Polakami coraz częściej pojawiają się klienci z Ukrainy, Czech, Słowacji czy Rosji, co jeszcze kilka lat temu należało do wielkiej rzadkości. Tabela 6 przedstawia wybrane pielgrzymki po świecie organizowane przez opisywane biuro podróży, miejsca, które są odwiedzane podczas pielgrzymki, cenę w dolach kanadyjskich, długość trwania wyjazdu oraz dostępne daty wyjazdowe pielgrzymek, które były w katalogowej ofercie biura na rok 2018. Z informacji uzyskanych podczas wywiadu z pracownicami biura wynika, że Queen Syrena Travel rocznie wysyła ok. 350 osób na różne pielgrzymki, podczas gdy w systemie danych personalnych widnieje baza ok. 3000 osób, którzy choć raz skorzystali z usług tego biura podróży.

Biuro podróży organizuje pielgrzymki o różnej długości trwania, od 7 do nawet 15 dni. Koszt takiego pielgrzymowania jest zróżnicowany i zależy przede wszystkim od miejsca, terminu oraz czasu trwania. Za pielgrzymkę do Guadalupe, trwającą 7 dni, trzeba zapłacić 2199 CAD, a za piętnastodniową pielgrzymkę do Włoch, Szwajcarii, Francji, Belgii, Niemiec i Holandii czy za pielgrzymkę do Czech, Polski, Austrii, Słowenii i Włoch trzeba już wydać ok. 4500 CAD i być przygotowanym na dwutygodniową podróż. Biuro 
Tabela 6. Wybrane pielgrzymki organizowane przez Queen Syrena Travel

\begin{tabular}{|c|c|c|c|c|}
\hline Pielgrzymka & Odwiedzane miejsca & $\begin{array}{c}\text { Cena } \\
\text { w CAD }\end{array}$ & $\begin{array}{c}\text { Liczba } \\
\text { dni }\end{array}$ & \begin{tabular}{|c|} 
Dostępne daty \\
pielgrzymki w 2018 r.
\end{tabular} \\
\hline $\begin{array}{l}\text { Pielgrzymka } \\
\text { do Lourdes } \\
\text { i Ziemi Świętej }\end{array}$ & $\begin{array}{l}\text { Lourdes, Tel Awiw, Cezarea, } \\
\text { Galilea, Kafarnau, Nazaret, Kana, } \\
\text { Jerycho, Hajfa, En Karem, Morze } \\
\text { Martwe, Betlejem, Jerozolima }\end{array}$ & 3769 & $11 \mathrm{dni}$ & 12-22 października \\
\hline $\begin{array}{l}\text { Pielgrzymka } \\
\text { do Czech, Polski, } \\
\text { Austrii, Słowenii } \\
\text { i Włoch }\end{array}$ & $\begin{array}{l}\text { Praga, Kraków, Wadowice, } \\
\text { Auschwitz, Łagiewniki, Wiedeń, } \\
\text { Lublana, Wenecja, Siena, Asyż, } \\
\text { Rzym, Watykan }\end{array}$ & 4490 & $15 \mathrm{dni}$ & 12-26 października \\
\hline $\begin{array}{l}\text { Pielgrzymka } \\
\text { do Czech, Polski, } \\
\text { Austrii, Słowenii } \\
\text { i Włoch }\end{array}$ & $\begin{array}{l}\text { Praga, Kraków, Wadowice, } \\
\text { Auschwitz, Łagiewniki, Wieden, } \\
\text { Lublana, Wenecja }\end{array}$ & 3890 & $11 \mathrm{dni}$ & 12-22 października \\
\hline $\begin{array}{l}\text { Pielgrzymka } \\
\text { do Włoch }\end{array}$ & $\begin{array}{l}\text { Wenecja, Siena, Asyż, Rzym, } \\
\text { Watyka }\end{array}$ & 3190 & $7 \mathrm{dni}$ & 20-26 października \\
\hline $\begin{array}{l}\text { Pielgrzymka } \\
\text { do Ziemi Świętej } \\
\text { i Jordanii }\end{array}$ & $\begin{array}{l}\text { Tel Awiw, Cezarea, Galilea, } \\
\text { Kafarnau, Nasaret, Kana, Jerycho, } \\
\text { Hajfa, En Karem, Morze Martwe, } \\
\text { Betlejem, Jerozolima, Petra }\end{array}$ & 3890 & $11 \mathrm{dni}$ & 19-29 października \\
\hline $\begin{array}{l}\text { Pielgrzymka } \\
\text { do Ziemi Świętej } \\
\text { (Izrael) }\end{array}$ & $\begin{array}{l}\text { Tel Awiw, Cezarea, Galilea, } \\
\text { Kafarnau, Nasaret, Kana, Jerycho, } \\
\text { Hajfa, En Karem, Morze Martwe, } \\
\text { Betlejem, Jerozolima }\end{array}$ & 3050 & $9 \mathrm{dni}$ & $\begin{array}{l}30 \text { października- } \\
7 \text { listopada }\end{array}$ \\
\hline $\begin{array}{l}\text { Pielgrzymka } \\
\text { do Ziemi Świętej } \\
\text { i Jordanii }\end{array}$ & $\begin{array}{l}\text { Tel Awiw, Cezarea, Galilea, } \\
\text { Kafarnau, Nasaret, Kana, Jerycho, } \\
\text { Hajfa, En Karem, Morze Martwe, } \\
\text { Betlejem i Jerozolima, góra Nebo, } \\
\text { Petra }\end{array}$ & 3890 & $12 \mathrm{dni}$ & $\begin{array}{l}30 \text { października- } \\
10 \text { listopada }\end{array}$ \\
\hline $\begin{array}{l}\text { Pielgrzymka } \\
\text { do Ziemi Świętej }\end{array}$ & \begin{tabular}{|l|} 
Cezarea, Tabgha, Nazaret, Kana, \\
góra Tabor, Góra Błogosławieństw, \\
rzeka Jordan, Hajfa, Akka, Qumrān, \\
Jerycho, Betlejem, Góra Oliwna, \\
Jerozolima, Masada, Morze Martwe \\
\end{tabular} & 3570 & $11 \mathrm{dni}$ & 9-19 listopada \\
\hline $\begin{array}{l}\text { Pielgrzymka } \\
\text { do Meksyku }\end{array}$ & $\begin{array}{l}\text { miasto Meksyk, Bazylika Matki } \\
\text { Bożej z Guadalupe, Chapultepec, } \\
\text { Puebla, Tlaxcala, Taxco } \\
\end{array}$ & 2199 & $7 \mathrm{dni}$ & 11-17 listopada \\
\hline $\begin{array}{l}\text { Pielgrzymka } \\
\text { do Ekwadoru }\end{array}$ & \begin{tabular}{|l|} 
Meksyk, Quito, Ekwador, \\
El Teleferico, Mitad del Mundo, El \\
Carchi, Lago San Pablo, Otavalo, El \\
Quinche, Banos, Riobamba, Biblian, \\
Cuenca, Loja, El Cisne \\
\end{tabular} & 4299 & $14 \mathrm{dni}$ & 2-15 maja \\
\hline $\begin{array}{l}\text { Pielgrzymka } \\
\text { do Medjugorje }\end{array}$ & \begin{tabular}{|l|} 
Medjugorie, Apparition Hill, Góra \\
Krzyża, Dubrownik \\
\end{tabular} & 2266 & $9 \mathrm{dni}$ & 30 sierpnia-7 września \\
\hline $\begin{array}{l}\text { Pielgrzymka } \\
\text { do Portugalii, } \\
\text { Hiszpanii } \\
\text { i Francji }\end{array}$ & $\begin{array}{l}\text { Lizbona, Santarém, Fatima, } \\
\text { Salamanca, Valinhos, Aljustrel, } \\
\text { Nazaré, Obidos, Coimbr, Braga, } \\
\text { Sanktuarium Bom Jesus do } \\
\text { Monte, Santiago de Compostela, } \\
\text { the Sanktuarium św. Stanisława } \\
\text { Ignacego Loyoli, Lourdes }\end{array}$ & 2890 & $10 \mathrm{dni}$ & $\begin{array}{l}27 \text { września- } \\
6 \text { października }\end{array}$ \\
\hline
\end{tabular}




\begin{tabular}{|l|l|c|c|c|}
\hline $\begin{array}{l}\text { Pielgrzymka } \\
\text { do Włoch, } \\
\text { Szwajcarii, } \\
\begin{array}{l}\text { Francji, Belgii, } \\
\text { Niemiec, } \\
\text { Holandii }\end{array}\end{array}$ & $\begin{array}{l}\text { Rzym, Assisi, Siena, Florencja, } \\
\text { Bolonia, Milan, Lucerna, Strasburg, } \\
\text { Riems, Paryż, Banneux, Akwizgran, } \\
\text { Kolonia, Amsterdam }\end{array}$ & 4490 & 15 dni & $13-27$ maja \\
\hline $\begin{array}{l}\text { Pielgrzymka do } \\
\text { Szkocji i Irlandii }\end{array}$ & $\begin{array}{l}\text { Edynburg, Perth, Glasgow, Belfast, } \\
\text { Knock, Galway, Klify Moheru, } \\
\text { Killarney, Pierścień Kerry, Dublin }\end{array}$ & 4190 & 13 dni & 23 sierpnia-5 września \\
\hline $\begin{array}{l}\text { Pielgrzymka do } \\
\text { Grecji i Włoch }\end{array}$ & $\begin{array}{l}\text { Ateny, Korynt, Termopile, Saloniki, } \\
\text { Filippi, Meteory, Delfy, Asyż, } \\
\text { Lanciano, San Giovanni Rotondo, } \\
\text { Monte Casino, Rzym }\end{array}$ & 4299 & 15 dni & $\begin{array}{c}26 \text { sierpnia-10 } \\
\text { września }\end{array}$ \\
\hline
\end{tabular}

Źródło: opracowanie własne

podroży nie wysyła swoich pielgrzymów tylko do Europy (do Czech, Polski, Austrii, Słowenii, Włoch, Hiszpanii, Portugalii, Grecji, Francji, Bośni i Hercegowiny, Irlandii, Szkocji czy Niemiec), ale także do Jordanii, Izraela, Meksyku czy Ekwadoru.

\section{Organizator obozów i kolonii - Camp Delfin}

Opisując biura podróży działająca w Greater Toronto Area, zwrócono również uwagę na działających na tym terenie organizatorów obozów i kolonii dla dzieci i młodzieży polskiego pochodzenia. Jednym z takich biur podróży jest Camp Delfin. Biuro działa od 25 lat i organizuje kolonie sportowe oraz spływy kajakowe dla dzieci i młodzieży w wieku 6-17 lat. Organizatorami są Tamara i Wiesław Ciejkowie, którzy są absolwentami AWF w Poznaniu, trenerami pływania i lekkiej atletyki, ratownikami Life Saving Society Canada - NLS, Red Cross \& CPR, Instr. YMCA - Canada. W tabeli 7 przedstawiono daty turnusów kolonijnych, które odbyły się w 2018 r., konieczny minimalny wiek uczestnika kolonii oraz cenę za jeden turnus.

Tabela 7. Wybrane turnusy kolonijne organizowane przez Camp Delfin

\begin{tabular}{|c|c|c|c|}
\hline Sesja & $\begin{array}{c}\text { Data } \\
\text { w 2018 r. }\end{array}$ & Rok urodzenia uczestnika & Opłata \\
\hline I & $1-7$ lipca & $2001-2013$ & $580+75$ HST $=\$ 655$ \\
\hline II & $8-14$ lipca & $2001-2013$ & $670+87$ HST $=\$ 757$ \\
\hline III & $15-21$ lipca & $2001-2013$ & $700+91 \mathrm{HST}=\$ 791$ \\
\hline IV & $5-11$ sierpnia & $2001-2013$ & $660+85$ HST $=\$ 745$ \\
\hline V & $12-18$ sierpnia & $2001-2009$ & $660+85$ HST $=\$ 745$ \\
\hline
\end{tabular}

Źródło: opracowanie własne

Kolonie mają dwa turnusy dziesięciodniowe i trzy turnusy siedmiodniowe. Organizowane są one w ośrodku wypoczynkowym przy Pigeon Lake, $50 \mathrm{~km}$ od Peterborough. Kolonie Delfin to typowo polskie kolonie - podczas wyjazdu uczestnicy rozmawiają w języku polskim, co jest dobrym atutem zwłaszcza, jeśli uczestnik kolonii nie urodził się w Polsce, jego pierwszym językiem nie jest język polski, a rodzice dbają o polską edukację dziecka. Na obozie jest tylko 50 uczestników podczas turnusu, a więc wszyscy się znają i jest im zapewnione bezpieczeństwo. 
Wnioski końcowe

Kanada plasuje się w czołówce krajów najczęściej odwiedzanych przez turystów zagranicznych. Notuje rocznie ponad $22 \mathrm{mln}$ przyjazdów turystów zagranicznych, którzy zostawiają w tym kraju coraz więcej pieniędzy. W 2015 r. zagraniczni turyści zasilili gospodarkę Kanady o 19,6 mld dolarów. Ogólna liczba wyjazdów Kanadyjczyków w 2016 r. to 261,4 mln, z czego najwięcej stanowiły podróże krajowe. Na podróże krajowe Kanadyjczycy wydali najwięcej pieniędzy - w 2014 r. było to 29700 mln dolarów.

Kanada znajduje się w czołówce światowej krajów o największych dochodach z turystyki zagranicznej i notuje bardzo dużo przyjazdów turystów spoza granic swojego kraju. W obu tych kategoriach plasuje się na 12 miejscu w światowym rankingu, natomiast 8 miejsce należy się Kanadzie pod względem wydatków turystów na wyjazdy zagraniczne.

W roku 2017 do Polski przyjechało ok. 90 tys. Kanadyjczyków. Najczęściej odwiedzali oni Polskę w miesiącach sezonu letniego. Najwięcej turystów z Kanady zanotowano w lipcu - było ich aż 12,7 tys., co stanowi 16,3\% ogółu Kanadyjczyków, którzy odwiedzili Polskę w roku 2017. Turyści z Kanady przyjeżdżali do Polski głównie w celu uprawiania turystyki sentymentalnej i poznawczej. Stosunkowo dużo, bo ok. 19\% turystów, deklarowało przyjazd do Polski w celu odwiedzin krewnych bądź znajomych. Zapewne tę grupę stanowią Polacy, którzy mają poza polskim obywatelstwem także obywatelstwo kanadyjskie i widnieją we wszystkich turystycznych spisach jako „Kanadyjczyk”. Odwiedziny rodziny i krewnych, czyli tzw. turystyka sentymentalna, odgrywają wśród Polonii kanadyjskiej szczególną rolę. Jak wynika z przeprowadzonych badań oraz co podkreślają pracownice polskich biur podróży, kupno biletu lotniczego do Polki za pośrednictwem polskich biur podróży w Greater Toronto Area stanowi znaczny udział wszystkich sprzedanych usług w każdym opisanym w artykule biurze. Jak powiedziała w przeprowadzonym wywiadzie Grażyna Pochron z Piast Travel Inc, sprzedaż biletów lotniczych do Polski odbywa się systematycznie przez cały rok, a ich liczba w skali roku wynosi kilkaset sztuk. Są to stali klienci, którzy w celach sentymentalnych podróżują do Polski zazwyczaj co dwa lata.

Kanada jest jednym z największych na świecie rynków generujących ruch turystyczny, a działalność polskich biur podróży w Greater Toronto Area jest jednym z motorów napędzających rozwój turystyki i to nie tylko na terenie Kanady. Z przeprowadzonych badań wynika, że działalność polskich biur podroży na kanadyjskim rynku odgrywa ogromną rolę w ogólnym sektorze turystycznym w Kanadzie. Działające polskie biura podróży na kanadyjskim rynku dają pracę wielu osobom, a mieszkającej tam Polonii dają komfort w sprzedaży produktów turystycznych w postaci wyjazdów oraz wszelkie bezpieczeństwo związane z formalnościami dokonywanymi przed wyprawą oraz opiekę podczas trwania samego wyjazdu.

Literatura

References

Alejziak, W. (2008). Metodologia badań w turystyce. W: R. Winiarski (red.), Turystyka w naukach humanistycznych. Warszawa: Wydawnictwo Naukowe PWN, 140-164.

Alejziak, W. (2005). Aktualny stan i perspektywy rozwoju badań naukowych nad turystyka. W: R. Winiarski, W. Alejziak (red.), Turystyka w badaniach naukowych. Kraków: AWF, Rzeszów: WSIZ, 275-299. 
Anisef, P., Lanphier, M. (2003). The World in the City. Toronto, Buffalo, London: University of Toronto Press.

City of Toronto: Toronto Facts, Toronto's racial diversity Ethnocultural Portrait of Canada, Census 2001 (2019, 20 stycznia). Pozyskano z: https://www150.statcan.gc.ca/n1/en/catalogue/97F0010X

Cook, S., Perry, T., Ward, G. (2001). USA - czesść zachodnia, praktyczny przewodnik. Bielsko-Biała: Wydawnictwo Pascal.

Fish, S. (1997). Boutique multiculturalism or why liberale are incapable of thinking about hale speech. Critical Inquiry, 23(2).

Hays, D. (2003; 2018, 19 listopada). Wielokulturowość w Kanadzie. Gazeta Uniwersytecka UŚ, 7(107). Pozyskano z: http://gazeta.us.edu.pl/node/216721

Jasiński, M., Kowalski, M. (2007). Fałszywa sprzeczność: metodologia jakościowa czy ilościowa?. W: A. Haber (red.), Ewaluacja ex post. Teoria i praktyka badawcza. Warszawa: Polska Agencja Rozwoju Przedsiębiorczości, 97-114

Kijewska-Trembecka, M. (2013). Wspótczesne wieloetniczne społeczeństwo Kanady. W: M. Gabryś, M. Kijewska-Trembecka, R. Rybkowski, T. Soroka (red.), Kanada na przełomie XX i XXI wieku. Polityka, społeczeństwo, edukacja. Kraków: Księgarnia Akademicka.

Marczuk-Karbownik, M. (2016). Stosunki polsko-kanadyjskie - problemy i wyzwania w XXI wieku. W: M. Pietrasiak, M. Stelmach, K. Żakowski (red.), Polityka zagraniczna Polski 25 lat doświadczeń. Uniwersytet Łódzki, 161-180.

Ministerstwo Spraw Zagranicznych. https://astana.msz.gov.pl/pl/p/msz_pl/polityka_zagraniczna/polonia/definicje_pojecia/ (2016). Definicje, pojęcia dotyczace spraw polonijnych.

Ministerstwo Spraw Zagranicznych (2015). Rządowy program wspótpracy z Polonia i Polakami za granica $w$ latach 2015-2020. Pozyskano z: http://www.iz.poznan.pl/en/file,download,22,de7f2be1509373c68e28f63156d77dc6/1268-Nowy-Program-Rzadowy.pdf

Ministerstwo Spraw Zagranicznych. Departament Konsularny (2014; 2018, 27 grudnia). Raport polskiej stużby konsularnej za 2013 rok. Pozyskano z: https://www.msz.gov.pl/pl/informacje_konsularne/ raporty_konsularne/raport_konsularny_2013.

Mamzer, H. (2003). Tożsamość w podróży. Wielokulturowość a ksztaltowanie tożsamości jednostki. Poznań: Wydawnictwo Naukowe UAM.

Reczyńska, A. (2014). Polska emigracja do Kanady w drugiej połowie XX w. i jej wplyw na przemiany polskiej grupy etnicznej w tym kraju. W: A. Branach-Kallas (red.), Niuanse wyobcowania. Diaspora i tematyka polska w Kanadzie. Toruń: Wydawnictwo Naukowe UMK, 15-36.

Reczyńska, A. (2010). Historyczne uwarunkowania kultury kanadyjskiej. W: E. Sojka, M. Buchholtz (red.), Państwo - naród - tożsamość w dyskursach kulturowych Kanady. Kraków: Universitas, $17-40$.

Reczyńska, A. (2006). Przemiany w społeczności polonijnej w Kanadzie pod koniec XX wieku. W: G. Babiński, H. Chałupczak (red.), Diaspora polska w procesach globalizacji. Stan i perspektywy badań. Kraków: Grell, 161-175.

Reczyńska, A. (2001). Polska diaspora w Kanadzie. W: A. Walaszek (red.), Polska diaspora. Kraków: Wydawnictwo Literackie, 30-50.

Reczyńska, A., Soroka, T. (2013). Polska emigracja do Kanady na przełomie wieków XX i XXI w kontekście kanadyjskiej polityki imigracyjnej. Studia Migracyjne - Przegląd Polonijny, 3, 5-18.

Statistics Canada (2017; 2018, 23 grudnia). Census of Population, http://www12.statcan.gc.ca/census-recensement $/ 2011 / \mathrm{dppd} /$ prof $/$ details $/$ page.cfm?Lang $=\mathrm{E} \& \mathrm{Geo} 1=\mathrm{PR} \&$ Code1 $=01 \& \mathrm{Geo} 2=$ PR\&Code2 $=01 \&$ Data $=$ Count $\&$ SearchText $=$ canada $\&$ SearchType $=$ Begin $s \& S e a r c h P R=01 \& B 1$ $=$ All\&Custom $=$ \&TABID $=1$

Statistics Canada (2006a). Immigration in Canada: A Portrait of the Foreign-born Population: Census 2006: Findings (2019, 14 stycznia). Pozyskano z: https://www12.statcan.gc.ca/census-recensement/2006/as-sa/97-557/index-eng.cfm 
Statistics Canada (2006b; 2019, 3 stycznia). Census, Ethnic Origins. Pozyskano z: https://www12.statcan. gc.ca/census-recensement/2006/rt-td/eth-eng.cfm

Statistics Canada (2019, 12 stycznia). 2001 Census. Pozyskano z: http://www12.statcan.ca/english/census01/home/index.cfm

Ziółkowska-Weiss. K. (2016). Znaczenie działalności polskich biur podróży w Chicago. Annales Universitatis Paedagogicae Cracoviensis Studia Geographica, X, 66-82.

Kamila Ziółkowska-Weiss, dr, Uniwersytet Pedagogiczny im. Komisji Edukacji Narodowej w Krakowie, Instytut Geografii, Katedra Turystyki i Badań Regionalnych. Autorka studiowała prawo oraz kulturoznawstwo z historią sztuki na Uniwersytecie Jagiellońskim. Jest również absolwentką geografii z podstawami przedsiębiorczości ukończonej na Uniwersytecie Pedagogicznym w Krakowie. Ukończyła podyplomowe studia na Uniwersytecie Ekonomicznym w Krakowie na kierunku zarządzanie turystyką międzynarodową. W 2015 r. z wyróżnieniem obroniła pracę doktorską, uzyskując tym samym tytuł doktora nauk o Ziemi. Od 2012 r. pracuje w Zakładzie Turystyki i Badań Regionalnych Uniwersytetu Pedagogicznego w Krakowie, gdzie prowadzi m.in. zajęcia z turystyki w Stanach Zjednoczonych Ameryki. Jest czynnym pilotem wycieczek oraz autorką kilkudziesięciu publikacji naukowych. Jej główne zainteresowania naukowe to Polonia w Ameryce Północnej i Południowej, turystyka kulturowa oraz mniejszości narodowe w Polsce.

Kamila Ziółkowska-Weiss, $\mathrm{PhD}$, graduate of Culture Studies and of Law at the Jagiellonian University and of Geography at the Pedagogical University of Krakow. She has graduated from postgraduate studies in international tourism management at the Cracow University of Economics. Since 2012 she has been a research worker, acting as an assistant in the Department of Tourism and Regional Studies of the Pedagogical University of Krakow. An active tourist guide. An author of several academic publications. Her main academic interests include cultural tourism, ethnic groups in Małopolska and Polish minority in North and South America.

ORCID: 0000-0001-6575-5314

\section{Adres/Address:}

Uniwersytet Pedagogiczny im. Komisji Edukacji Narodowej

Instytut Geografii

Katedra Turystyki i Badań Regionalnych

ul. Podchorążych 2

30-084 Kraków, Polska

e-mail: kamilazw@up.krakow.pl 